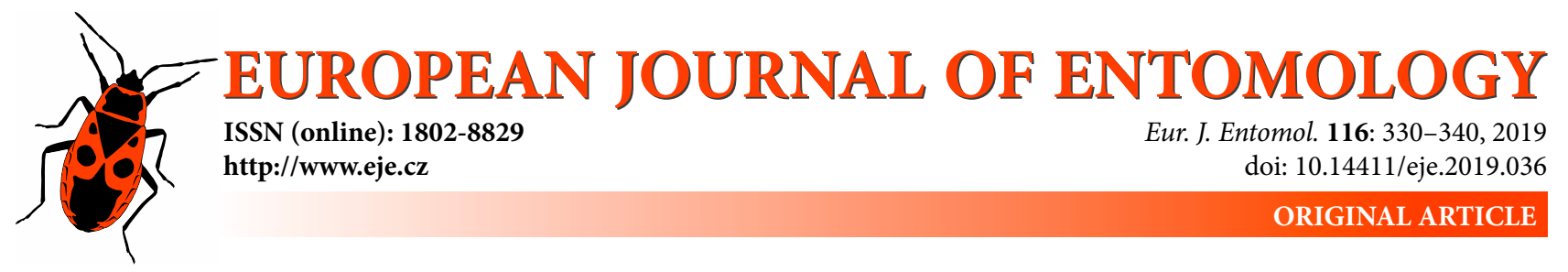

\title{
Camarochiloides weiweii gen. n. \& sp. n., the first representative of Pachynomidae (Hemiptera: Heteroptera) from Borneo
}

\author{
Zhuo CHEN, YingQ LIU, Hu LI and WANZH CAI* \\ Department of Entomology and MOA Key Lab of Pest Monitoring and Green Management, College of Plant Protection, \\ China Agricultural University, Beijing 100193, China; e-mails: insectchen625@126.com, liuyingqi@cau.edu.cn, \\ tigerleecau@hotmail.com, caiwz@cau.edu.cn
}

Key words. Hemiptera, Heteroptera, Pachynomidae, Pachynominae, Camarochiloides weiweii, new genus, new species, Oriental Region, Borneo

\begin{abstract}
The family Pachynomidae is recorded from Borneo as well as Southeast Asia for the first time. Camarochiloides gen. $\mathrm{n}$. and its type species $C$. weiweii sp. $\mathrm{n}$. is described. Dorsal habitus and various morphological characters of the new species are illustrated. Subfamily placement and affinities of the new genus are briefly discussed, a key to the genera of Pachynominae is provided. Body and wing polymorphism and nymphal morphology of the new species are documented.
\end{abstract}

ZooBank Article LSID: 98548326-3E86-4F5E-A108-1B8E5B996EFA

\section{INTRODUCTION}

The family Pachynomidae occurs widely in tropical and subtropical areas around the world, but there are only four genera with 29 species recorded so far (Carayon \& Villiers, 1968; Schuh \& Slater, 1995; Schuh et al., 2015; C. Weirauch, D. Forero \& R.T. Schuh, in prep.). Because of its appearance, the first species Pachynomus picipes (Klug, 1830) was placed in Reduviidae (Pachynomus was established as a subgenus of Reduvius). Stål (1873) later transferred Pachynomus to Nabidae and erected the subfamily Pachynominae to accommodate it, which was adopted in many subsequent studies (Uhler, 1894; Lethierry \& Severin, 1896; Distant, 1904; Reuter \& Poppius, 1909; Harris, 1930, 1931, 1940), except by Reuter (1908) who moved Aphelonotus Uhler to Reduviidae. Based on a series of anatomic features, Carayon (1950) points out that Pachynomidae have their closest relationship with Reduviidae. The most comprehensive revision of Pachynomidae was published by Carayon \& Villiers (1968), who treated this group as a separate family within Reduvioidea, established the currently accepted two-subfamily classification scheme, and provided synonymic and distributional information for all known species. Subsequent phylogenetic analyses consistently are highly supportive of monophyletic Pachynomidae, Reduviidae and Reduvioidea (Schuh \& Štys, 1991; Schuh \& Slater, 1995; Schuh et al., 2009; Zhang et al., 2016; Weirauch et al., 2019).
Although Pachynomidae superficially resemble some Nabidae, they share several synapomorphies with Reduviidae (e.g., the presence of antennal trichobothria, metathoracic Brindley's gland and paired pseudospermathecae) and also possess some autapomorphies such as a subdivided antennal pedicel and abdominal trichobothria (Carayon \& Villiers, 1968; Wygodzinsky \& Lodhi, 1989; Schuh \& Štys, 1991; Schuh \& Slater, 1995; Weirauch, 2003; Schuh et al., 2009). Despite their key systematic position among the Cimicomorpha, little is known about the biology and phylogeny within Pachynomidae. At the generic level, only Aphelonotus and Camarochilus Harris have been revised in detail (Schuh et al., 2015; C. Weirauch et al., in prep.). Nymphs of Pachynominae are as yet unknown (C. Weirauch et al., in prep.) and those of Aphelonotinae were only recently documented (Schuh et al., 2015). Most specimens in museums were collected using light traps or from leaf litter, indicating that Pachynomidae might be nocturnal ground-dwelling predators (Miller, 1971; Schuh \& Slater, 1995; Schuh et al., 2015; C. Weirauch et al., in prep.).

During our field expeditions in Borneo, we collected several specimens of a species of Pachynomidae. Further research and discussion revealed it should be accommodated in a new genus. In this paper, Camarochiloides weiweii gen. n. \& sp. n. is described and illustrated. This species shows astonishing dimorphism. The placement and affinities of the new genus are discussed briefly, and the body

\footnotetext{
* Corresponding author; e-mail: caiwz@cau.edu.cn
} 
and wing polymorphism and nymphal morphology of the new species are also documented.

\section{MATERIAL AND METHODS}

This study is mainly based on specimens preserved in the Entomological Museum of China Agricultural University, Beijing, China (CAU). For comparative purposes (mainly for construction of the key to genera) we also examined the Pachynomidae collection deposited in the Natural History Museum, London, U.K. $(\mathrm{BMNH})$. Male genitalia were soaked in hot $10 \% \mathrm{KOH}$ solution for approximately five minutes to remove soft tissue, rinsed in distilled water and dissected under a Motic binocular dissecting microscope. Dissected genitalia were placed in vials with glycerine and pinned under the corresponding specimens after examination. All of the photographs were taken using a Canon 7D Mark II digital camera with Canon micro lens EF $100 \mathrm{~mm}$ and MP-E 65 $\mathrm{mm}$ for habitus and an Olympus BX51 microscope for dissected body parts. Helicon Focus version 5.3 was used for image stacking. Measurements were obtained using a calibrated micrometer. Morphological terminology follows Carayon \& Villiers (1968), Rédei \& Tsai (2011) and C. Weirauch et al. (in prep.).

\section{TAXONOMY}

Genus Camarochiloides Chen, Liu, Li \& Cai, gen. n. (Figs 1-48, 50-51)

ZooBank taxon LSID:

A5254675-5096-4EB5-872F-1A555E53CF2A

Type species. Camarochiloides weiweii Chen, Liu, Li \& Cai, sp. n.

\section{Diagnosis}

Brachypterous or macropterous (Figs 1-6, 50, 51); body surface coarsely granulated; labial segments II and III subequal in length (Figs 8, 11); lateral margin of pronotum constricted (Figs 7, 10); sculpture on pronotum with anterior lobe partly smooth and posterior lobe strongly granulated (Figs 7, 10); paired trichobothrium-bearing knob-like processes located near anterior angles and at both ends of the transverse sulcus (Figs 1, 4, 7, 10); metapleuron flat, as high as long (Figs 8, 11); corium with four (brachypterous form, Fig. 16) or six (macropterous form, Fig. 17) longitudinal rows of granulations; posterior margin of corium oblique (Fig. 17); membrane without free-ending veins (Fig. 17); abdominal sternite II with indistinct parastigmal pits; pygophore with paired protuberances (Figs 33-35).

\section{Description}

Brachypterous male (Figs 1-3). Coloration: Body generally brownish red tinged with brownish yellow, membrane dark grey.

Structure: Body oblong, body surface strongly granulated and wrinkled; head, scape, labium and legs moderately shining; meso- and metapleura rugose; head, antennae, labium, pronotum, legs and ventral surface of abdomen sparsely covered with short setae; scutellum and fore wing with decumbent, tiny setae; distal pseudosegment of pedicel and flagellomeres densely covered with decumbent or suberect, short setae; dorsal and ventral surface of head, labium with several erect, long setae; ventral surface of fore trochanter, fore- and mid femora with rows of modified, stout, spine-like setae, interspersed with erect, long setae (Figs 20, 23); ventral surface of fore trochanter and -femur densely covered with erect, long pubescence; ventral surface of fore- and mid tibiae each with a row of erect or suberect, short setae intermixed with a row of small denticles (Figs 21, 24); hind tibia with several suberect, strong setae; tiny fossula spongiosa on apex of fore- and midtibiae (Figs 22, 25); abdominal sternites III-VIII with a pair of trichobothria on either side of midline, trichobothrium on sternite III in a submedian position and more lateral on each subsequent segment, trichobothrium VIII at level of trichobothrium IV (Fig. 27).

Head (Figs 7-9) moderately elongate, with a distinct constriction behind eyes; eyes distinctly protruding laterally, reniform in lateral view, dorsal margin barely surpassing vertex and ventral margin far remote from ventral surface of head (Fig. 8); scape stout, reaching apex of head, pedicel slenderer than scape, flagellomeres slenderer than pedicel, about as long as combined scape and pedicel; labium (Fig. 8) curved, reaching anterior margin of prosternum, first segment triangular, second and third segments subequal in length, fourth segment tapered. Pronotum (Fig. 7) trapezoidal, with distinct anterior collar, lateral margins distinctly concave, posterior margin distinctly concave, leaving mesoscutum largely exposed; anterior lobe distinctly longer than posterior lobe, partly smooth, with a deep median longitudinal sulcus, on each side near the middle with a wide, rugose depression; posterior lobe marked off by a deep, slightly curved transverse sulcus, strongly granulated, with humeral angles rounded; pronotum with two pairs of trichobothrium-bearing knob-like processes, one situated near anterolateral angles, another situated on both ends of the transverse sulcus (Fig. 7); fore acetabulum open (Fig. 9). Scutellum (Fig. 7) triangular, with anterolateral calli, either side of median longitudinal ridge finely rugose, apex acute, with a granulated tubercle; mesopleuron (Fig. 8) rugose; mesosternum (Fig. 9) rugose, with a median longitudinal ridge. Metapleuron (Fig. 8) flat, rugose, as high as long; metasternum with a median longitudinal ridge. Fore trochanter somewhat flattened, with an apical protuberance (Figs 1, 13); fore femur (Fig. 13) strongly thickened, ventrally flattened, with rows of numerous modified, stout, spine-like setae, interspersed with erect, long setae; mid femur (Fig. 14) slender, ventrally with two rows of spinelike setae; hind femur (Fig. 15) very slender, unarmed; fore- and mid tibiae (Figs 13-14) slender, slightly curved, hind tibia (Fig. 15) straight; tarsi (Figs 22, 25-26) 3-segmented, with first segment extremely short, third segment longer than combined length of first and second segments. Fore wing (Fig. 16) brachypterous, reaching middle of abdominal tergite II (Fig. 28), with corium, clavus and membrane well developed; corium and clavus with four rows of granulated ridges; membrane veins reduced. Abdomen (Figs 27-28) oval; spiracle I on mediotergite I, spiracles II-VII on mediosternites ventral to the ventral connexival suture; abdominal sternite II with indistinct parastigmal pits; mediosternites III-VII each with a sinuous transverse ridge near its anterior margin. 

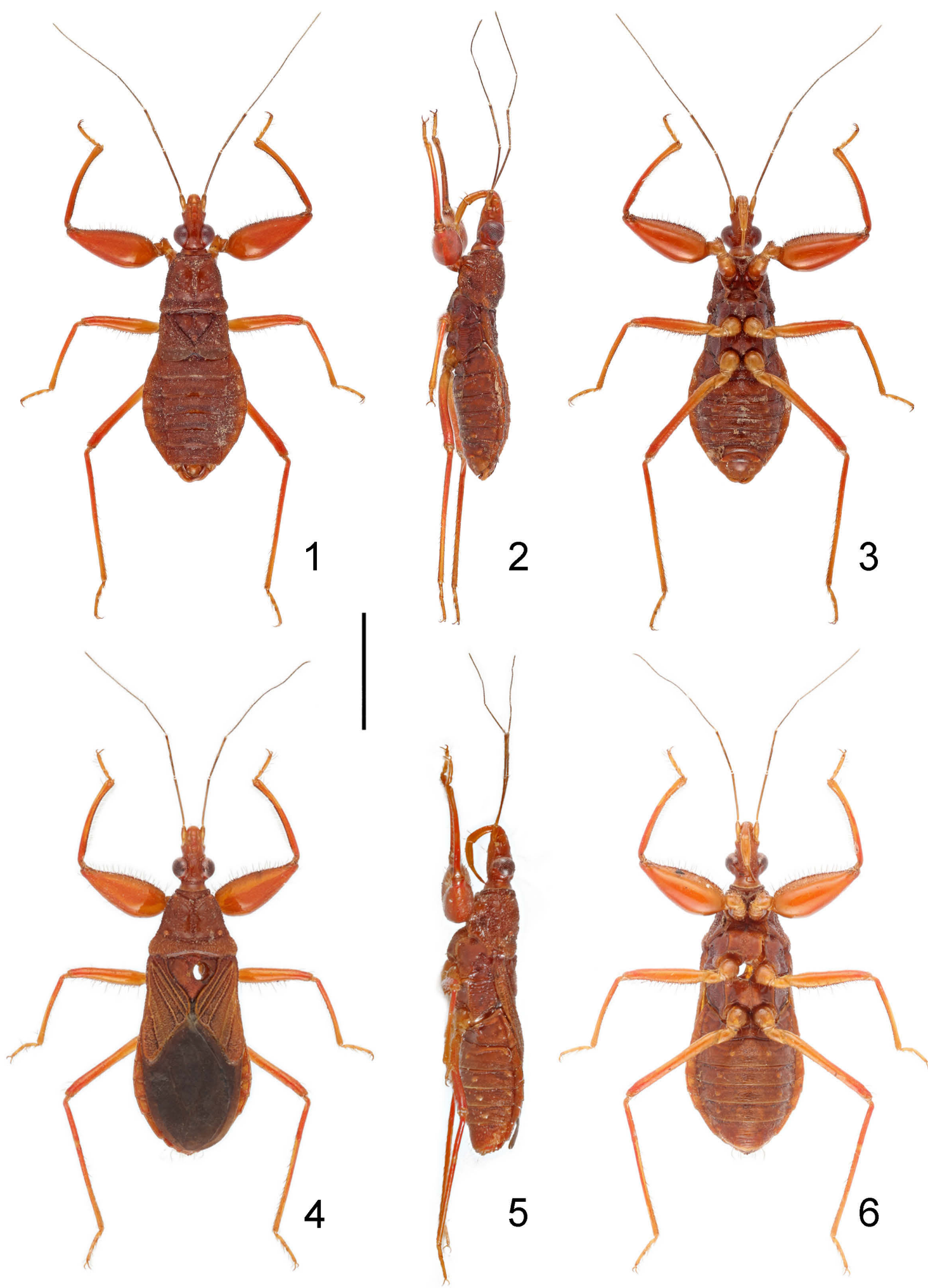

Figs 1-6. Camarochiloides weiweii Chen, Liu, Li \& Cai, sp. n., habitus. 1-3 - brachypterous male paratype; 4-6 - macropterous female paratype. 1, 4-dorsal view; 2, 5- lateral view; 3, 6 - ventral view. Scale bar $=3.00 \mathrm{~mm}$.

Male genitalia: Pygophore (Figs 33-35) symmetrical, with a pair of anterolateral protuberances; parameres (Figs 28, 36-43) asymmetrical, crossed when at rest, strongly bent, with blade-shaped apical portion; phallus (Figs 4446) stout, arched, endosoma with large membranous processes.
Macropterous female (Figs 4-6) similar to male in body shape, but lighter in coloration and much bigger in size. Pronotum (Fig. 10) broader than long, with anterior lobe distinctly narrower than posterior lobe. Mesopleuron and mesosternum (Figs 11-12) smoother than in male, mesosternum densely covered with pubescence, median longitu- 


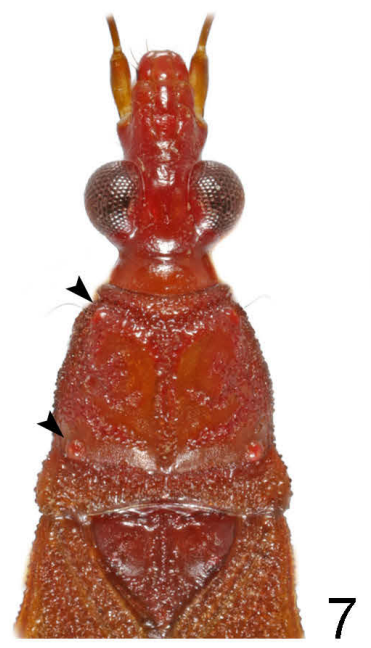

7
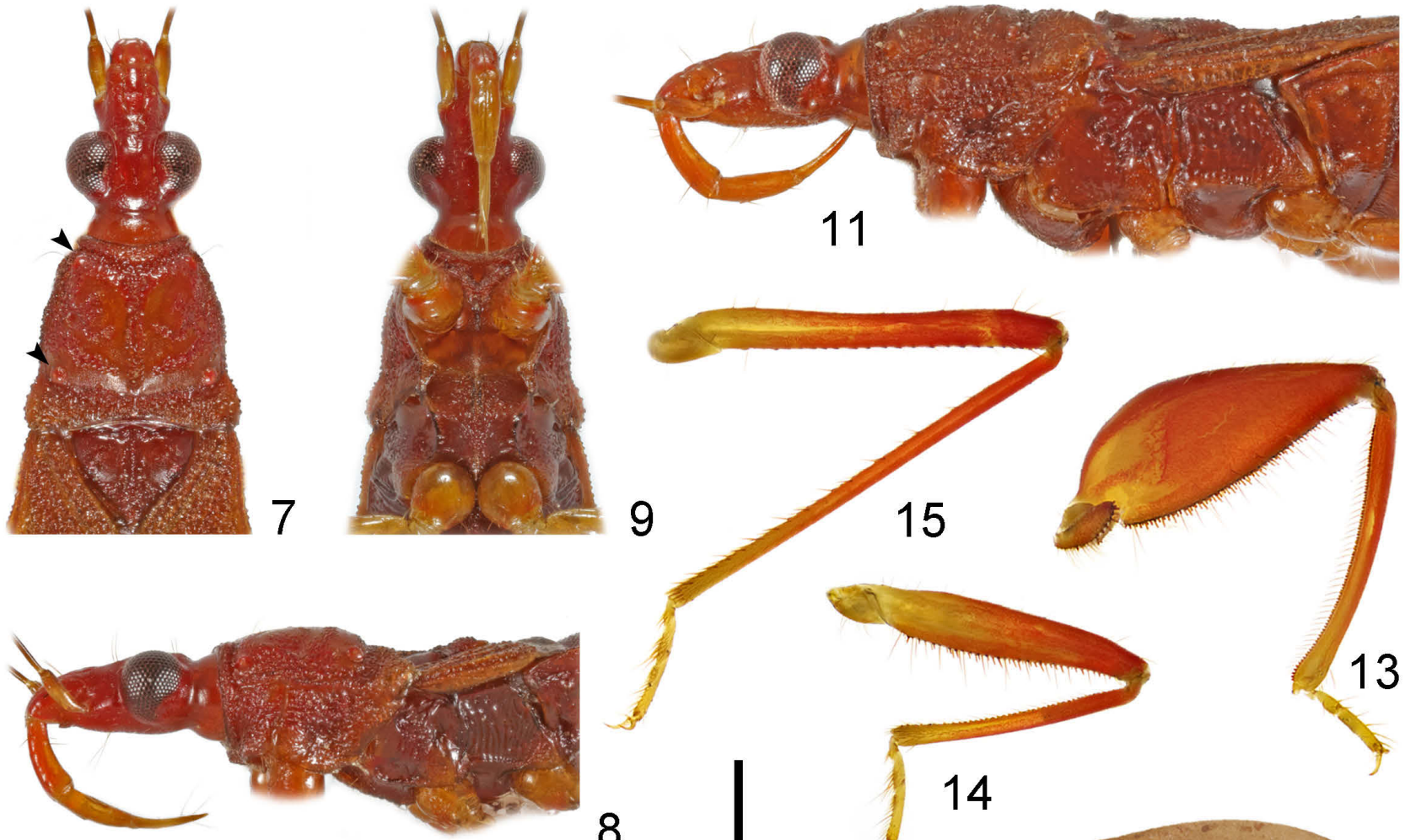

14
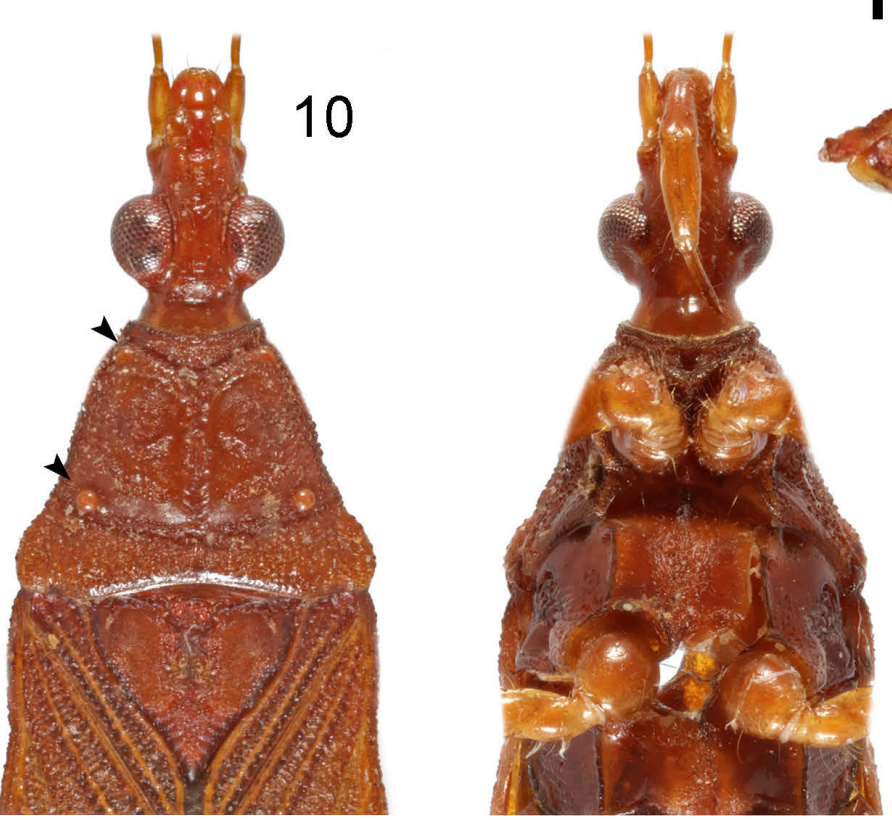

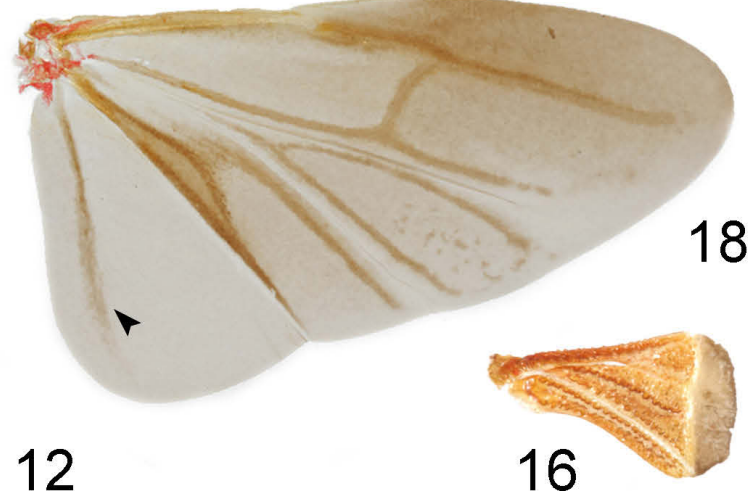

16

Figs 7-18. Camarochiloides weiweii Chen, Liu, Li \& Cai, sp. n. 7-9, 16 - male holotype; 10-15, 17-18 - female paratype. 7-12 - anterior part of body, with antennae and legs removed, arrows indicate trichobothrium-bearing knob-like processes; 13 - left fore leg; 14 - left mid leg; 15 - left hind leg; 16-17 - right fore wing; 18 - right hind wing, arrow indicates A2. 7, 10, 16-18 - dorsal view; 8, 11 - lateral view; 9 , $12-15-$ ventral view. Scale bar $=1.00 \mathrm{~mm}$.

dinal ridge weakly developed. Fore wing (Fig. 17) macropterous, with endocorium and exocorium clearly separated by medial fracture, costal fracture absent; corium and clavus with six longitudinal rows of granulations; membrane with two cells, free-ending veins absent. Hind wing (Fig. 18) with hamus absent, secondary veins distinct, Pcu and A1 form complex venation.

Female genitalia (Fig. 30): Mediotergites IX and X clearly separated, flanked by paratergite IX; valvifer I broad, plate-shaped; valvula I and styloid visible in resting state.

Brachypterous female: One specimen (Fig. 50) was collected along with the female paratype (Figs 4-6, 51). Unfortunately, it was originally erroneously assumed to be a nymph and used for DNA extraction. The specimen is badly damaged (although we were able to confirm it is a brachypterous female), cannot be satisfactorily described and was therefore excluded from the type material. 

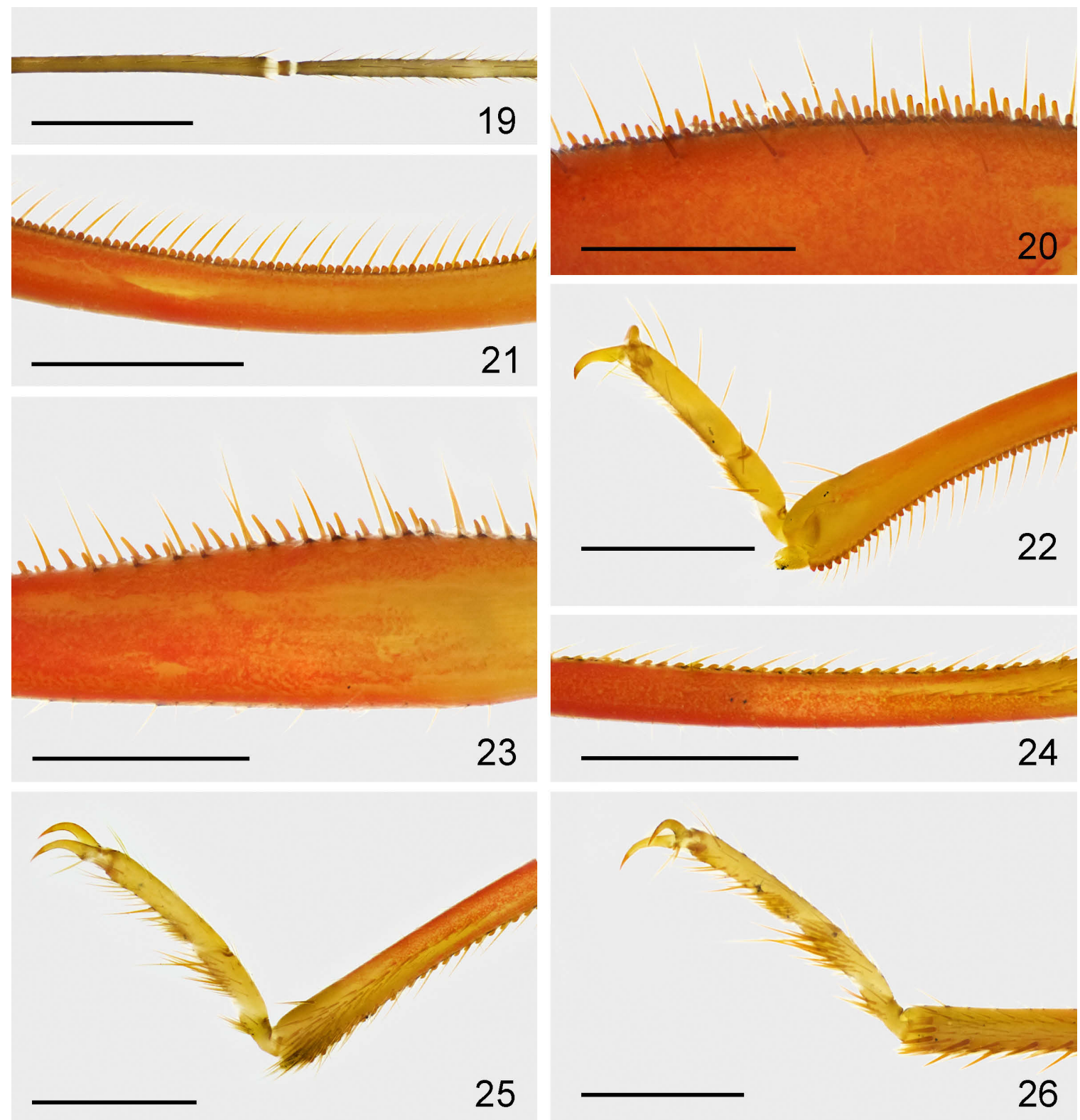

Figs 19-26. Camarochiloides weiweii Chen, Liu, Li \& Cai, sp. n., female paratype. 19 - pedicel; 20 - medial part of fore femur; 21 - medial part of fore tibia; 22 - anterior part of fore leg; 23 - medial part of mid femur; 24 - medial part of mid tibia; 25 - anterior part of mid leg; 26 - anterior part of hind leg. Scale bar $=0.50 \mathrm{~mm}$.

Etymology. The generic name is derived from Camarochilus (a genus of Pachynomidae which is similar to the new one) and the Greek suffix -ides (meaning similar). Gender masculine.

Distribution. Borneo.

Subfamily placement. Camarochiloides gen. n. could be placed in the subfamily Pachynominae by a combination of the following characters: ocelli absent (vs. ocelli present in Aphelonotinae), posterior margin of corium oblique (vs. posterior margin of endocorium truncate in Aphelonotinae), and trichobothria on abdominal segments III-VIII (vs. trichobothria only on segments VI-VIII in Aphelonotinae). These two subfamilies are diagnosed by Carayon \& Villiers (1968) and keyed by Schuh \& Slater (1995).

The hind wing venation of Pachynomidae was studied by Davis (1961) and Carayon \& Villiers (1968). Based on the venation of the postcubital sector (formed by Pcu and A1), Davis (1961) discusses the similarity between Pachynomidae and Nabidae. Carayon \& Villiers (1968) presume that the postcubital sector has systematic importance. They mention and illustrate the differences in hind wing venation in the two subfamilies they recognized, pointing out that the vein formed by Pcu and A1 is branched in Pachynominae, but simple in Aphelonotinae. Although the phylogenetic importance of the postcubital sector is unclear, we illustrate the hind wing of the new species (Fig. 18), which indicates that Camarochiloides gen. n. should be treated as a member of Pachynominae.

The differences in male genitalia between Pachynominae and Aphelonotinae are mentioned by Carayon \& Villiers (1968). They indicate that the pygophore of Pachynominae is ornamented with a pair of anterolateral protuberances 

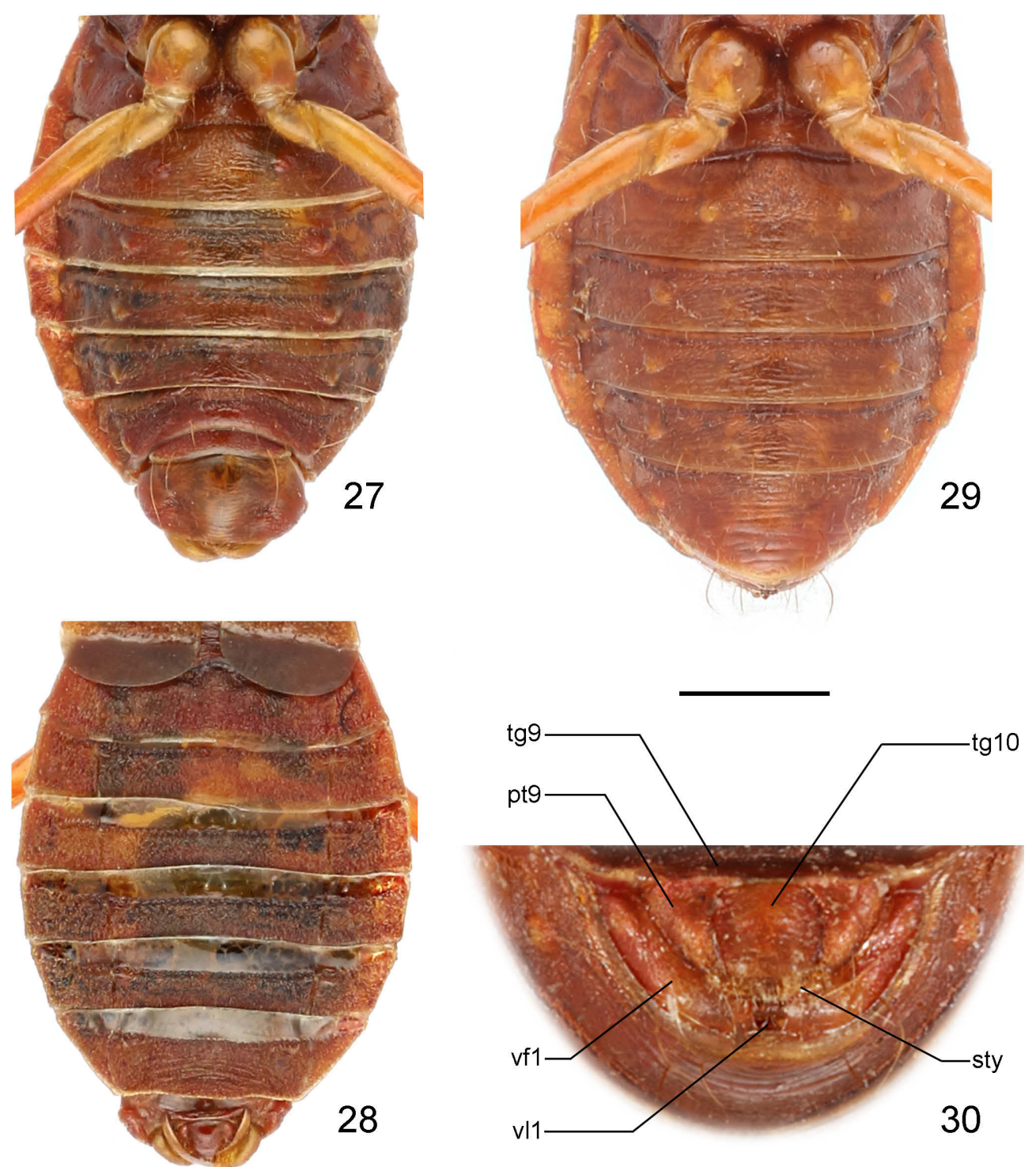

Figs 27-30. Camarochiloides weiweii Chen, Liu, Li \& Cai, sp. n. 27-28 - male holotype; 29-30 - female paratype. 27-29 - abdomen; 30 - apical part of abdomen. 27,29 - ventral view; 28 - dorsal view; 30 - caudal view. Scale bars: $27-29=1.00 \mathrm{~mm} ; 30=0.50 \mathrm{~mm}$.

and the phallus is entirely enclosed in the pygophore. In Aphelonotinae, the pygophore lacks protuberances, the phallus is elongated and tubular, with its apex extending into the pregenital segments. Recently, C. Weirauch et al. (in prep.) illustrate the male genitalia of Camarochilus species, and reveal the taxonomic importance of the pygophore protuberances, the parameres and the asymmetric degree of genitalia at the species level. We provide illustrations of pygophore, parameres and phallus of $C$. weiweii sp. n. below (Figs 33-46). These characters also indicate that Camarochiloides gen. $\mathrm{n}$. belongs to the Pachynominae.

Comparative notes. Camarochiloides gen. n. superficially resembles the Neotropical genus Camarochilus, but can be differentiated by a combination of the following characters: labial segments II and III subequal in length (vs. labial segment II about half as long as III in Camarochilus); the sculpture on pronotum with anterior lobe partly smooth and posterior lobe strongly granulated (vs. anterior lobe smooth and posterior lobe rugose in Camarochilus); the paired trichobothrium-bearing knob-like processes on pronotum (vs. pronotum without such processes in Camarochilus); the corium with four or six longitudinal rows of granulations (vs. with six or seven rows in Camarochilus); the inner angle of corium nearly rectangular (vs. inner angle obtuse in Camarochilus); the metapleuron as high as long (vs. metapleuron longer than wide in Camarochilus); mid and hind legs with tarsomere III twice as long as II (vs. tarsomeres II and III subequal in length in Camarochilus).

The new genus is similar to the Old World genera Pachynomus and Punctius in several respects. Besides its much smaller size and highly granulated body surface, Camarochiloides gen. n. differs from Pachynomus by its subequal labial segments II and III (vs. labial segment II distinctly shorter than III in Pachynomus); the lateral pronotal margin concave (vs. convex in Pachynomus); the corium with four or six longitudinal rows of granulations (with two rows in Pachynomus); the posterior margin of corium oblique (vs. 

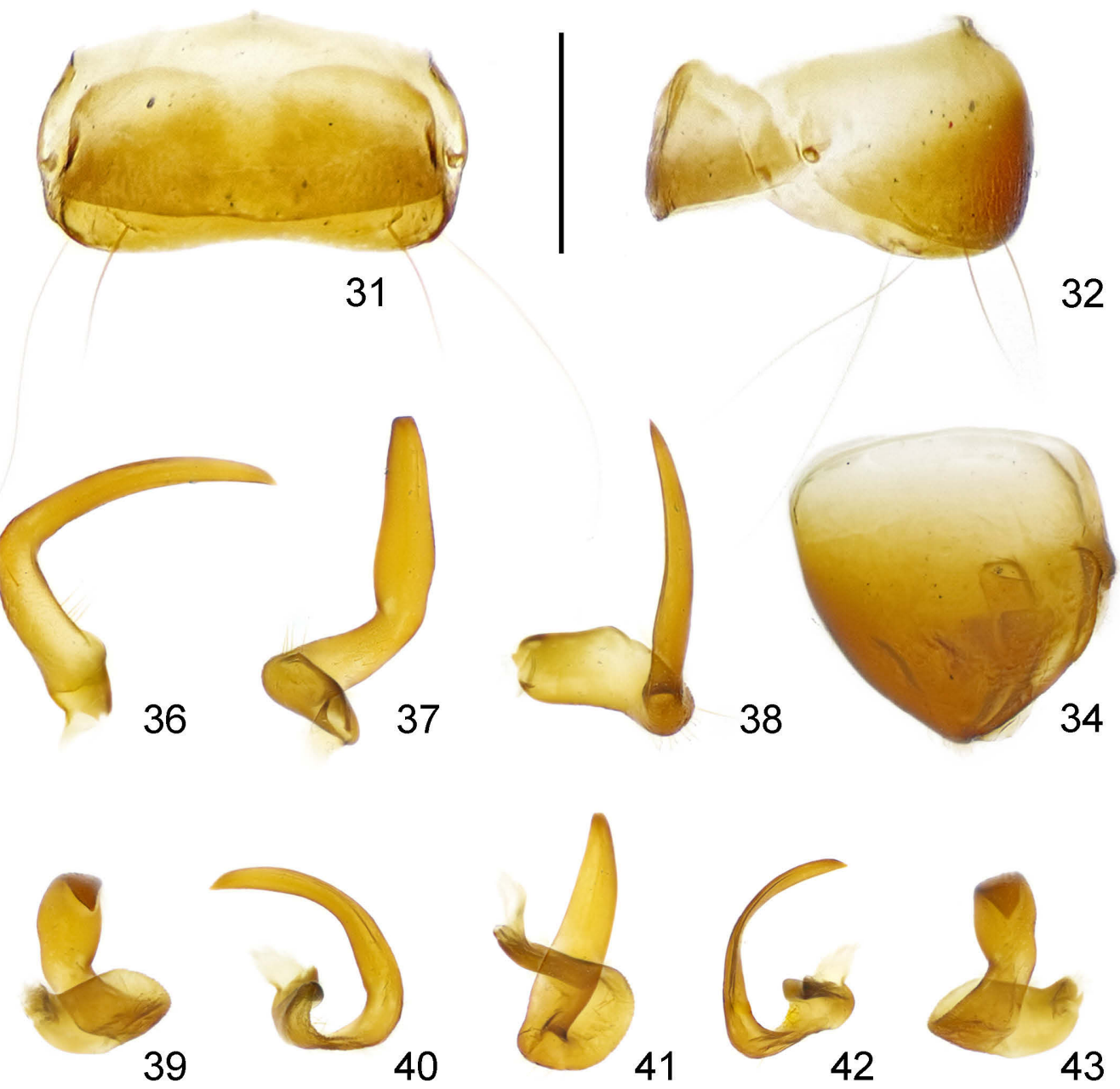

39

40
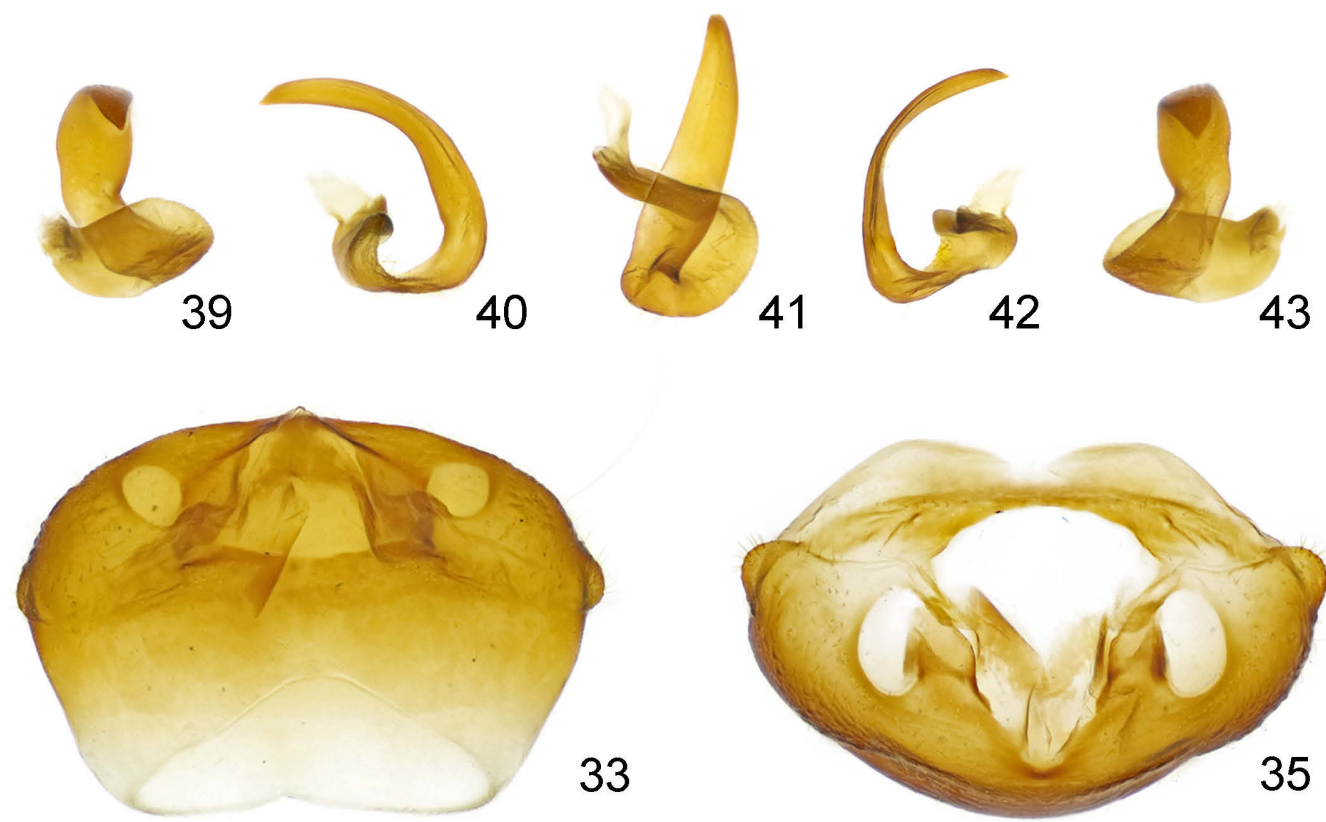

Figs 31-43. Camarochiloides weiweii Chen, Liu, Li \& Cai, sp. n., male holotype. 31-32 - abdominal segment VIII; 33-35 - pygophore; $36-38$ - right paramere; $39-43$ - left paramere. 31 - ventral view; 32 , 34 - lateral view; 33 - dorsal view; 35 - caudal view. Scale bar = $0.50 \mathrm{~mm}$.

transverse in Pachynomus); the absence of a costal fracture (vs. costal fracture present in Pachynomus); the absence of free-ending veins on the membrane (vs. free-ending veins present in Pachynomus); and the indistinct parastigmal pits on abdominal sternite II (vs. parastigmal pits very distinct in Pachynomus). The new genus differs from Punctius by its labial segment IV slightly shorter than II or III (vs. segment IV distinctly shorter than II or III in Punctius); the concave lateral pronotal margin (vs. convex in Punctius); the sculpture on the pronotum with the anterior lobe partly smooth and posterior lobe strongly granulated (vs. both lobes finely rugose in Punctius); the corium with four or six longitudinal rows of granulations (vs. with four or five rows in Punctius); the rectangular inner angle of corium (vs. inner angle obtuse in Punctius); parastigmal pits on abdominal sternite II indistinct (vs. parastigmal pits absent in Punctius). Additionally, the trichobothrium-bearing knoblike processes are absent in Pachynomus and Punctius.

Genera of the subfamily Pachynominae can be distinguished using the key below. Although male genitalia constitute important species level features in Camarochilus (C. Weirauch et al., in prep.), such characters are poorly 


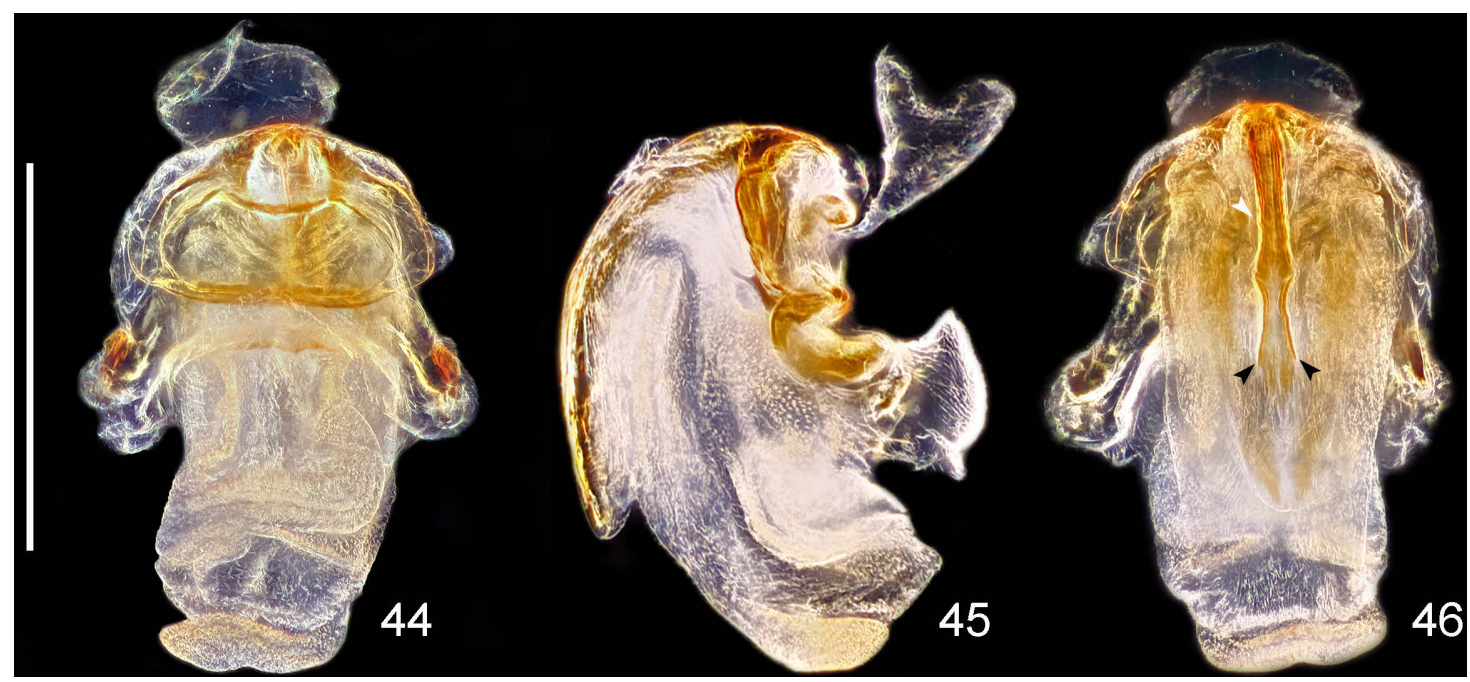

Figs 44-46. Camarochiloides weiweii Chen, Liu, Li \& Cai, sp. n., male holotype, phallus. 44 - dorsal view; 45 - lateral view; 46 - ventral view, white arrow indicates pedicel, black arrows struts. Scale bar $=0.50 \mathrm{~mm}$.

documented for the members of Pachynomus and Punctius, therefore the taxonomic importance of male genitalia at the generic level is unclear.

\section{Key to the genera of Pachynominae}

1 Body length over $10 \mathrm{~mm}$, highly polished; corium with two rows of granulations; posterior margin of corium transverse; costal fracture present; membrane with numerous free-ending veins ....................................................Pachynomus Klug

- Body length less than $10 \mathrm{~mm}$, dull to moderately shining; corium with four or more rows of granulations; posterior margin of corium oblique; costal fracture faint or absent; membrane without free-ending veins .

2 Labial segments II and III subequal in length; corium with four to six rows of granulations; metapleuron as high as long

- Labial segment II about half as long as III; corium with six or seven rows of granulations; metapleuron longer than wide ... .. Camarochilus Harris

3 Labial segment IV slightly shorter than II or III; lateral pronotal margin concave; pronotum with two pairs of trichobothrium-bearing knob-like processes; corium with four (brachypterous) or six (macropterous) rows of granulations.. . Camarochiloides gen. $\mathrm{n}$.

- Labial segment IV distinctly shorter than II or III; lateral margin of pronotum convex; trichobothrium-bearing knob-like processes absent; corium with four or five rows of granulations .

Punctius Stål

Camarochiloides weiweii Chen, Liu, Li \& Cai, sp. n.

(Figs 1-48, 50-51)

ZooBank taxon LSID:

49019F53-7379-4FAB-9741-3C2EC11D5E2A

\section{Diagnosis}

Body length about $6.9-8.4 \mathrm{~mm}$, brachypterous ( 0 and P) or macropterous ()); body brownish red tinged with brownish yellow, membrane dark grey; body surface strongly granulated and wrinkled; fore femur about 2.4 2.5 times as long as its greatest width; in brachypterous form, pronotum about 0.8 times as long as its greatest width, fore wing reaching middle of abdominal tergite II; in macropterous form, pronotum about 0.7 times as long as wide, fore wing reaching apex of abdomen; pygophore symmetric, parameres asymmetric.

\section{Description}

Brachypterous male (Figs 1-3). Coloration: Body generally brownish red. Colour of head (Figs 7-9) same as that of body; clypeus, mandibular plate, maxillary plate, labrum and ventral surface of labial segment II lighter; apex of labial segment II, segments III and IV brownish yellow; eyes black; basal 2/3 of scape light brown; apex of scape, pedicel (including intrapediceloid), flagellomeres brown. Colour of pronotum (Fig. 7) same as that of body; anterior margin, lateral margins and transverse sulcus with an indistinct black outline; posterior pronotal lobe and posterior margin of propleuron lighter. Pleura and sterna of mesoand metathoraxes darkish red; mid and hind acetabulum brownish yellow; anterior margin of metapleuron, mid and lateral ridges on mesosternum, mid ridge on metasternum black. Colour of legs same as that of body; fore leg (Fig. 13) with coxa, trochanter, basal $1 / 3$ of femur, apex of tibia, tarsus lighter; mid leg (Fig. 14) with coxa, trochanter, basal $3 / 4$ of femur, apex of tibia, tarsus lighter; hind leg (Fig. 15) with coxa, trochanter, basal $1 / 3$ of femur, apex of tibia, tarsus lighter. Fore wing (Fig. 16) with longitudinal rows of granulations darker, membrane dark grey. Colour of abdomen same as that of body; border of each mediotergites with black transverse ridges (Fig. 28).

Structure: Body oblong, body surface and vestiture as in generic description. Length of head about 1.2 times as long as the width across eyes; eyes large, width across eyes about 3.3 times as broad as interocular space; antennae as in generic description, proximal pseudosegment of pedicel slightly longer than the distal one, distiflagellum about twice as long as basiflagellum; labium as in generic description, second segment thickened at apex. Pronotum as in generic description, length of pronotum about 0.8 times as long as its greatest width, anterior lobe about 4.4 times as long as posterior lobe; median longitudinal sulcus with 

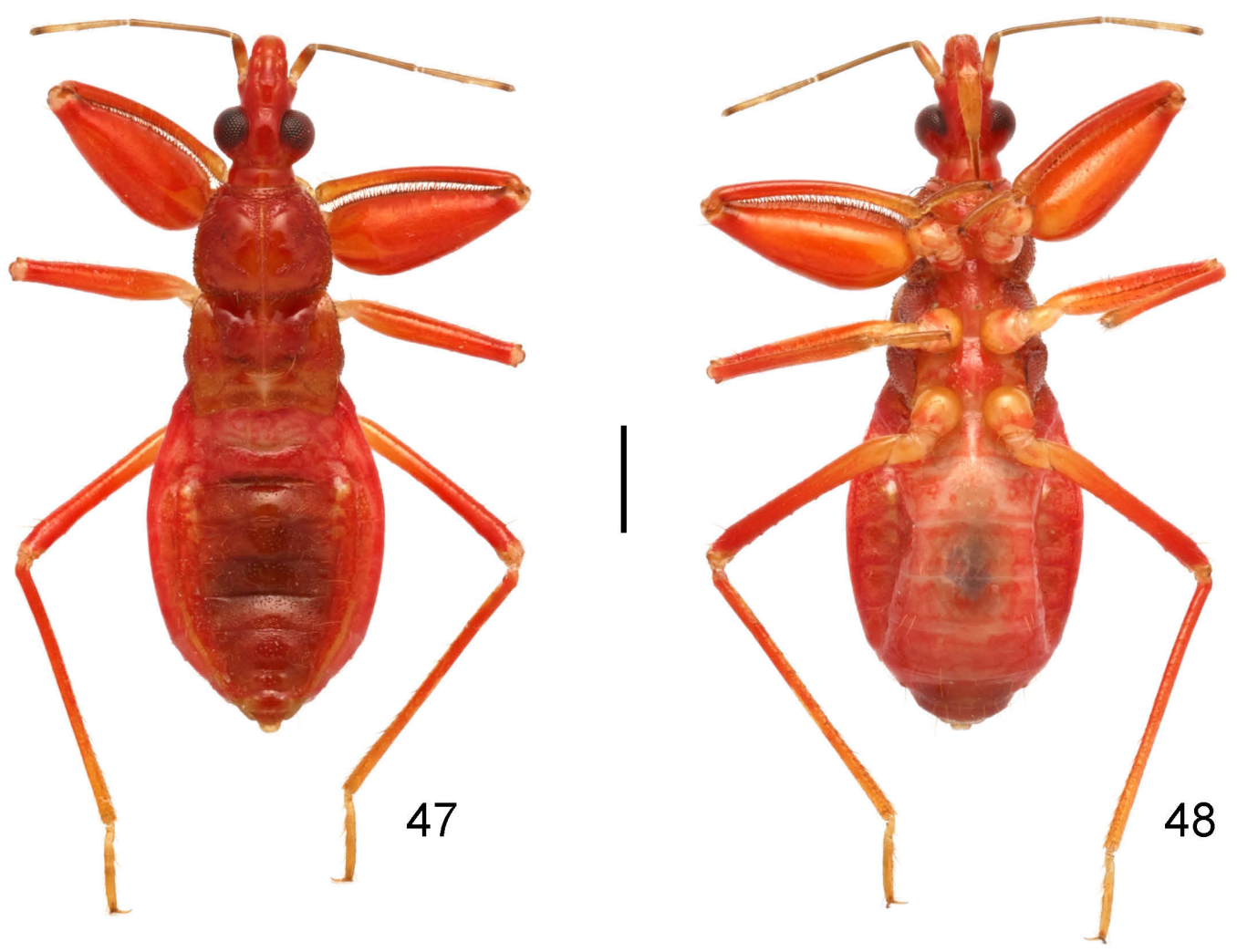

Figs 47-48. Camarochiloides weiweii Chen, Liu, Li \& Cai, sp. n., nymph. $47-$ dorsal view; $48-$ ventral view. Scale bar $=1.00 \mathrm{~mm}$.

sinuous rugosity. Fore femur about 2.4 times as long as its greatest width; fore tibia subequal in length to that of fore femur, apex with a tibial comb and a fossula spongiosa (Fig. 22); mid femur about 5.3 times as long as its greatest width; claws paired, simple. Fore wing brachypterous, reaching middle of abdominal tergite II, with four rows of granulations, membrane veins reduced; hind wing very small, bud-shaped, veins reduced. Abdomen about 1.3 times as long as its greatest width; parastigmal pit on abdominal sternite II ventral to spiracle II, indistinct; tergite VIII (Figs 27, 31-32) distinctly exposed in ventral view, anterior margin convex, posterior margin concave, with a pair of macrosetae (sensu Schuh et al., 2015).

Male genitalia: At rest as shown in Fig. 28. Pygophore as shown in Figs 33-35. Parameres (Figs 36-43) inserted on posterior half of pygophore, right paramere (Figs 36-38) sickle-shaped, left paramere (Figs 39-43) strongly bent. Phallus as shown in Figs 44-46: articulatory apparatus broad, strongly sclerotized; basal plates with basal half thickened and apical half flat and curved, basal plate bridge narrow and straight, capitate processes small; pedicel (Fig 46, white arrow) long and narrow, strongly sclerotized, with a swollen apex; 1+1 struts (Fig 46, black arrows) narrow, basal $1 / 2$ slightly curved and separated at apex; endosoma with large membranous processes dorsally.

Macropterous female (Figs 4-6). Coloration: Similar to male but lighter; membrane dark grey, veins same colour as the remainder of membrane; hind wing grey, with veins darkish grey; posterior margin of mediotergites II-VII with a transverse grey stripe.
Structure: As in generic description. Head about 1.3 times as long as width across eyes; width across eyes about 3.4 times as broad as interocular space. Pronotum about 0.7 times as long as its greatest width, anterior lobe about 3.3 times as long as posterior lobe. Fore femur about 2.5 times as long as its greatest width; fore tibia about 0.9 times as long as fore femur; mid femur about 6.0 times as long as its greatest width. Fore wing macropterous, reaching apex of abdomen, with six rows of granulations; membrane with two cells, anterior one formed by $\mathrm{M}$ and $\mathrm{Cu}$, posterior one by $\mathrm{Cu}$ and $\mathrm{A} 1$. Hind wing broad, as shown in Fig. 18. Abdomen about 1.3 times as long as its greatest width; parastigmal pit on abdominal sternite II very indistinct.

Female genitalia: As in generic description.

Brachypterous female: See generic description.

Measurements [type specimens, in $\mathrm{mm}, \hat{\sigma}(\mathrm{n}=3) / q$ $(\mathrm{n}=1)]$. Length of body (to apex of abdomen) $6.90-7.20$ / 8.35; length of head 1.20-1.45 / 1.40; width across eyes $1.00-1.10 / 1.10$; interocular space $0.30 / 0.32$; length of antennal segments $\mathrm{I}-\mathrm{V}=0.40 / 0.45,1.05-1.20 / 1.22$, 0.90-1.00/1.09, 0.90-1.00/1.00, $1.90 / 2.00$; length of labial segments II-IV $=0.70-0.80 / 0.80,0.70 / 0.70,0.55-$ $0.60 / 0.55$; length of pronotum 1.35-1.40 / 1.52; length of anterior pronotal lobe 1.10-1.20 / 1.15; length of posterior pronotal lobe $0.20-0.25 / 0.35$; width of anterior pronotal lobe $0.95-1.35 / 1.80$; width of posterior pronotal lobe 1.64-1.70 / 2.25; median length of scutellum 0.80-0.85 / 1.15 ; basal width of scutellum $0.90 / 1.25$; length of fore femur, tibia, tarsus $=2.20-2.30 / 2.50,2.10-2.20 / 2.30$, $0.65-0.70 / 0.75$; greatest width of fore femur $0.90-0.92$ / 

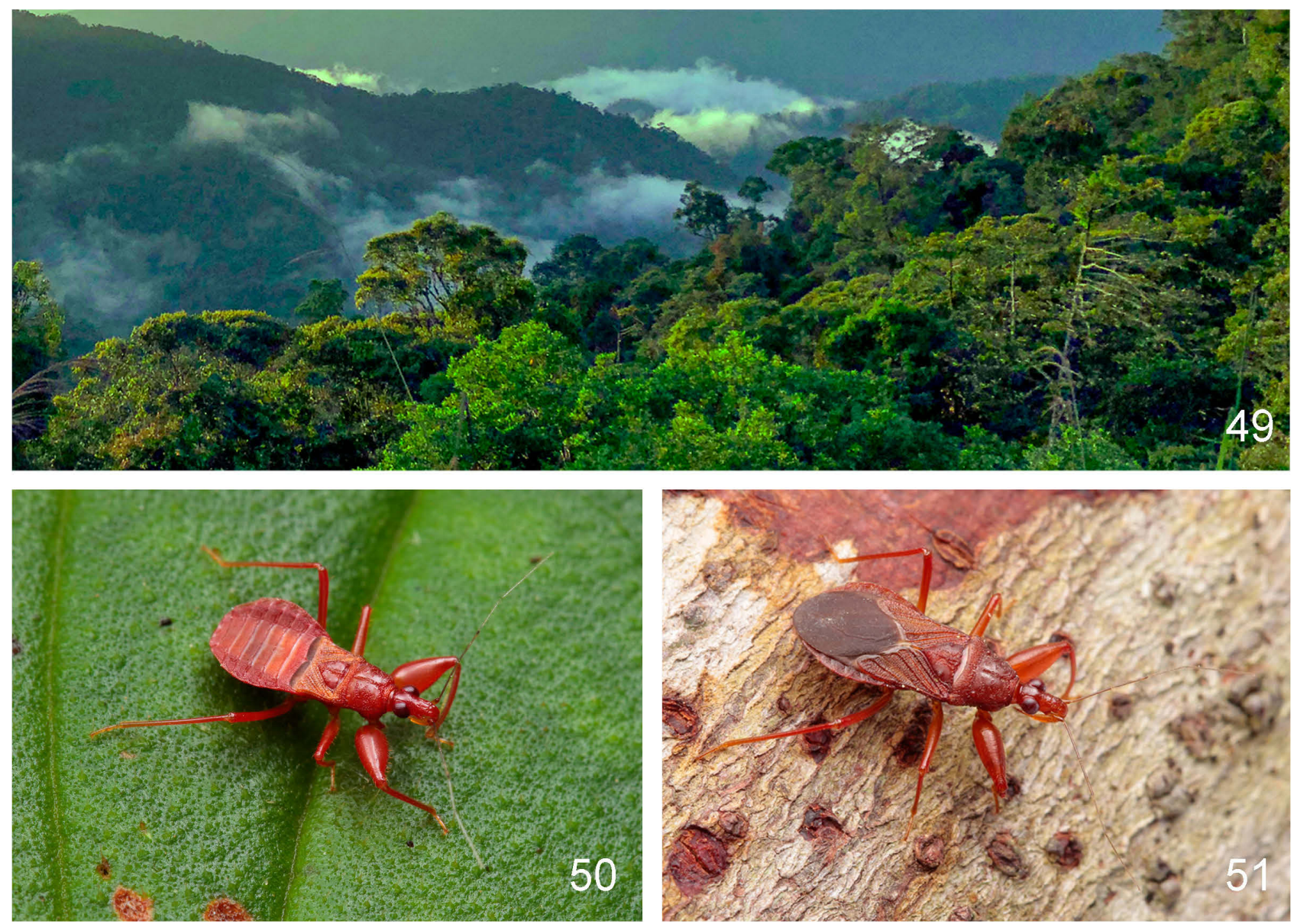

Figs 49-51. Camarochiloides weiweii Chen, Liu, Li \& Cai, sp. n. 49 - landscape at the type locality; 50 - living brachypterous female (๑ Jianyun Wang); 51 - living macropterous female paratype (@ Jianyun Wang).

1.00 ; length of mid femur, tibia, tarsus $=1.85-2.00 / 2.40$, $1.80-1.85 / 1.95,0.70-0.75 / 0.80$; greatest width of mid femur $=0.35-0.40 / 0.40$; length of hind femur, tibia, tarsus $=2.40-2.65 / 2.95,3.15-3.20 / 3.60,0.85-0.90 / 0.90$; length of fore wing $1.30 / 5.10$; width of corium $0.95 /$ 1.20 ; length of abdomen 3.40-3.45 / 3.85; greatest width of abdomen 2.62-2.70 / 3.05.

Type material. Holotype: Brachypterous $\hat{\partial}$, MALAYSIA, Sabah, Mt. Trus Madi, Borneo Jungle Girl Camp, 5 ${ }^{\circ} 26^{\prime} 55.7^{\prime \prime} \mathrm{N}$, $116^{\circ} 27^{\prime} 08.6^{\prime \prime} \mathrm{E}$, light trap, 14.viii.2016, leg. Yisheng Zhao (CAU). Paratypes: 1 macropterous $\circ$, same locality as holotype, alt. 1115 m, light trap, 13.x.2015, leg. Jianyun Wang (CAU); 1 brachypterous $\hat{\partial}$, same locality as holotype, under decaying log, 23.vii.2019, leg. Zelun Li (CAU); 1 brachypterous $\widehat{\partial}$, same locality as holotype, under stone, 26.vii.2019, leg. Zelun Li (CAU).

Other material examined. 1 brachypterous $P$, same locality as type specimens, light trap, 13.x.2015, leg. Jianyun Wang (CAU, in ethanol, damaged); nymph (instar uncertain), same locality as type specimens, under decaying log, 30.iv.2018, leg. Zhaoyang Chen (CAU, in ethanol).

Type locality. Malaysia, Sabah, Mt. Trus Madi, Borneo Jungle Girl Camp, 526'55.7"N, $116^{\circ} 27^{\prime} 08.6^{\prime \prime} \mathrm{E}$.

Etymology. The specific epithet is dedicated to the Chinese entomologist Weiwei Zhang, in honour of his contributions to entomology and help with our research.

Distribution. Known only from the rainforest on Mt. Trus Madi, Sabah, East Malaysia.
Biology of this species remains unknown, three adult specimens were collected using light traps, two adult males and an immature specimen were found hiding under decaying logs or stones (Zhaoyang Chen, pers. comm.; Zelun Li, pers. comm.).

Body and wing polymorphism. Sexual dimorphism appears to be uncommon in Pachynomidae and is only briefly mentioned by Schuh et al. (2015) in Aphelonotus and C. Weirauch et al. (in prep.) in Camarochilus. Type specimens of Camarochiloides weiweii sp. n. include only brachypterous males and a macropterous female. However, a brachypterous female specimen (Fig. 50) showing distinct similarities to the brachypterous males was collected along with the macropterous female paratype (Figs 4-7, 51); thus, the remarkable wing dimorphism in Camarochiloides is not sexual. Unfortunately, that brachypterous female was erroneously assumed to be a nymph and used for DNA extraction. Although the specimen was badly damaged and cannot be used for morphological comparisons, we were able to confirm it is a female.

Wing polymorphism is commonly recorded in the Heteroptera, with different types of wing modification recognized (Schuh \& Slater, 1995), but seems rather rare among the Pachynomidae; it is documented in the male of Aphelonotus simplus Uhler (Schuh et al., 2015) and the female of Camarochilus americanus Harris (C. Weirauch et al., 
in prep.), but it is possible that it also occurs in other species of Pachynomidae. Wing polymorphism often occurs in both sexes (and may occur also in the male of Camarochiloides weiweii sp. n., but more specimens are needed to confirm this hypothesis), but can be restricted to one sex occasionally, e.g., in some Reduviidae (Wygodzinsky, 1966). Differences between the macropterous and brachypterous specimens of Camarochiloides weiweii sp. n. are striking. In addition to the darker body coloration, the brachypterous specimens (males) are distinctly smaller than the female, with fore wings only reaching the middle of abdominal tergite II. Corium, clavus and membrane of the fore wing are recognizable, but there are only four longitudinal rows of granulations (six rows in the macropterous female), veins on membrane are absent (veins present and form two cells in the macropterous female), and the hind wing is strongly reduced, bud-shaped (broad with clear venation in macropterous female). Wing reduction is usually accompanied by thoracic modification; the anterior pronotal lobes of males are more developed and arched dorsally, with the posterior lobe narrower, ratio of pronotal length to its greatest width being 0.8 ( 0.7 in the macropterous female). The mesopleuron and mesosternum are smoother in female than in male, medial ridge of mesosternum weakly developed in female.

Nymphal morphology. Habitus images of a nymph (instar uncertain) are provided (Figs 47-48). The nymph is similar to the adult in body shape and coloration, several adult characters are present in nymphs. In addition to having undeveloped wings and reproductive organs, nymphs differ from adults, firstly, in having weakly developed thoracic sterna, but well sclerotized nota and pleura; secondly, fossula spongiosa is only present on the fore tibia; thirdly, pairs of macrosetae are present on the dorsum of the abdomen (absent in adults); fourthly, trichobothria are present on the antennae, pronotum and ventrally on the abdomen in both stages, but the bothrium in nymphs is weakly developed; fifthly, dorsal abdominal glands are present on the anterior margins of abdominal terga IV and V (absent in adults).

ACKNOWLEDGEMENTS. We are greatly obliged to P. Švácha (Institute of Entomology, Czech Academy of Sciences, České Budějovice) and two anonymous reviewers for helpful comments and critical reading of the manuscript. We sincerely thank C. Weirauch (University of California, Riverside) for her helpful advice during this research. We are grateful to M.D. Webb (The Natural History Museum, London) for his kind help in the examination of Pachynomidae specimens. We are also thankful to J. Wang for providing photographs of the living adults, and to $\mathrm{Z}$. Chen and Z. Li for providing information about the biology of the new species. This work was supported by grant from the National Natural Science Foundation of China (No. 31730086).

\section{REFERENCES}

CARAYON J. 1950: Caractères anatomiques et position systématique des Hémiptères Nabidae (Note préliminaire). - Bull. Mus. Natl. Hist. Nat. 22: 95-101.

Carayon J. \& Villiers A. 1968: Étude sur les Hémiptères Pachynomidae. - Ann. Soc. Entomol. Fr. (N.S.) 4: 703-739.
DAVIS N.T. 1961: Morphology and phylogeny of the Reduvioidea (Hemiptera: Heteroptera). Part II. Wing venation. - Ann. Entomol. Soc. Am. 54: 340-354.

Distant W.L. 1903/1904: The Fauna of British India, Including Ceylon and Burma. Rhynchota 2 (Heteroptera). Taylor and Francis, London, 503 pp. [pp. 1-242 (1903), pp. 243-503 (1904)].

HARris H.M. 1930: XVIII. Notes on some South American Nabidae, with descriptions of new species (Hemiptera). - Ann. Carnegie Mus. 14: 241-248.

Harris H.M. 1931: The genus Aphelonotus (Hemiptera, Nabidae). - Bull. Brooklyn Entomol. Soc. 24: 13-20.

HARRIS H.M. 1940: Some new and heretofore unrecorded Nabidae (Hemiptera). - Iowa St. Coll. J. Sci. 14: 323-332.

KLUG J.C.F. 1830: Symbolae physicae, seu icones et descriptiones insectorum, quae ex itinere per African borealem et Asiam. In Hemprich F.G. \& Ehrenberg C.H. (eds): Studio Novae aut Illustratae Redierunt. II. Berolini, pl. 11-20.

Lethierry L. \& Severin G. 1896: Catalogue Général des Hémiptères. Tome III. Hétéroptères. Friedländer \& Fils, Berlin, 275 pp.

MiLLER N.C.E. 1971: The Biology of the Heteroptera (2nd revised ed.). E.W. Classey, London, xiii +206 pp., 5 pls.

RÉDEI D. \& TsAa J.-F. 2011: The assassin bug subfamilies Centrocnemidinae and Holoptilinae in Taiwan (Hemiptera: Heteroptera: Reduviidae). - Acta Entomol. Mus. Nat. Prag. 51: 411-442.

Reuter O.M. 1908: Bemerkungen über die Nabiden nebst Beschreibung neuer Arten. - Mém. Soc. Entomol. Belg. 15: 87-130.

Reuter O.M. \& Poppius B. 1909: Monographia Nabidarum orbis terrestris. I. - Acta Soc. Sci. Fenn. 37(2): 1-62.

Schun R.T. \& Slater J.A. 1995: True Bugs of the World (Hemiptera: Heteroptera). Cornell University Press, Ithaca and London, $\mathrm{xii}+337 \mathrm{pp}$.

SchUn R.T. \& ŠTYs P. 1991: Phylogenetic analysis of cimicomorphan family relationships. - J. N. Y. Entomol. Soc. 99: 298-350.

Schun R.T., Weirauch C. \& Wheeler W.C. 2009: Phylogenetic relationships within the Cimicomorpha (Hemiptera: Heteroptera): a total-evidence analysis. - Syst. Entomol. 34: 15-48.

Schun R.T., Weirauch C. \& Grillo H. 2015: Revision of Aphelonotus Uhler (Hemiptera: Heteroptera: Pachynomidae), with description of six new species and documentation of nymphal morphology for three species. - Am. Mus. Novit. 3829: 1-43.

STÅL C. 1873: Enumeratio Hemipterorum, III. - K. Sven. Vetensk. Akad. Handl. (N.F.) 11(2): 1-163.

UHLER P.R. 1894: On the Hemiptera - Heteroptera of the Island of Grenada. - Proc. Zool. Soc. Lond. 1894: 167-224.

WeIrauch C. 2003: Pedicellar structures in Reduviidae (Heteroptera) - comments on cave organ and trichobothria. - Eur. J. Entomol. 100: 571-580.

Weirauch C., Schuh R.T., Cassis G. \& Wheeler W.C. 2019: Revisiting habitat and lifestyle transitions in Heteroptera (Insecta: Hemiptera): insights from a combined morphological and molecular phylogeny. - Cladistics 35: 67-105.

WygodZINSKY P. 1966: A monograph of the Emesinae (Reduviidae, Hemiptera). - Bull. Am. Mus. Nat. Hist. 133: 1-614.

WYGODZINSKY P. \& LoDHI S. 1989: Atlas of antennal trichobothria in the Pachynomidae and Reduviidae (Heteroptera). - J. N. Y. Entomol. Soc. 97: 371-393.

Zhang J., Gordon E.R.L., Forthman M., Hwang W.S., Walden K., Swanson D.R., Johnson K.P., Meier R. \& Weirauch C. 2016: Evolution of the assassin's arms: insights from a phylogeny of combined transcriptomic and ribosomal DNA data (Heteroptera: Reduvioidea). - Sci. Rep. 6: 22177, 8 pp.

Received July 6, 2019; revised and accepted September 9, 2019 Published online October 11, 2019 